\title{
University-of-the-Future's Role in Gender Fairness: Providing Fair Access to Balanced Education and Decent Work in Afghanistan
}

\author{
Latifa Hussaini \\ Kulliyah of Information and Communication Technology, \\ International Islamic University of Malaysia, Kuala Lumpur, Malaysia
}

\begin{abstract}
Traditionally, Afghanistan has remained a hotbed of gender inequality in various aspects. Women and girls encounter numerous hindrances in the education sector. Despite concerted efforts to enhance the educational system in the past several years, the situation of Afghan girls and women education continues deplorable. There is still much work to be done in enhancing education, in particular female literacy. This paper aims to explain the main barriers that hinder girls and women of access to education. It utilizes the design and system thinking methodology to describe the main obstacles and suggest a business model of the University of the Future (UotF) for a Malaysian university in providing fair access to a balanced education and decent work for girls and women in Afghanistan. The augmentation of this paper is a conceptual and validated business model in the BMC and VPC format. The proposed UotF business model for the Malaysian university will help Afghan females to obtain entrepreneurship education, experiences, and human values in contributing to the wellbeing and improvement of the Afghan nation.
\end{abstract}

Keywords:- Balanced Education, Gender Inequality, Entrepreneurship, Afghan women, BMC, VPC, Decent Work, Sustainable development, University of the future, SDG5.

\section{INTRODUCTION}

Gender equality in education is a basic human right it is also essential to achieving sustainable development. In our increasingly globalized world, the societies that succeed best will be those which guarantee women and girls equal access to education, thereby giving them the skills and the opportunities to develop their talents and interests, so they can contribute to building stronger and more resilient communities. In Islam, knowledge, its acquisition, and implementation, is an essential requirement for all Muslims to empower them to believe, think, and behave according to the principles of the religion [1]. So, it represents a change in mental and social ability to investigate, think and practice based on the values of Islam. Thus, access to education is right every human being, especially women. It helps to improve the economy and reduce poverty.
As stated by [2], in the past few years, the number of Afghan educated citizens has increased remarkably with 66 percent of males but only 37 percent of female. Whereas maybe quality of the education is not ensured due to the teachers face many challenges in 'delivering high good quality education including low wages, insecurity, lack of supplies and resources, and being understaffed. As reported by UNICEF recently, 3.7 million school-age children are out of school while 60 percent of them are girls. Insufficient female teachers, particularly in rural regions could be one of the reasons for the women and girl women and girl 's low registration. Lower than 20 percent of all teachers are female in the Afghan provinces [3].

Gender equality continues to be a major problem to human development. Over the past few decades, huge steps have been taken towards girls' and women's education, but they have not achieved gender equity yet. These obstacles vary from supply-side limitations to the negative norms and beliefs. The education of girls is hugely caused to be unsteady by the lower level of family' attention and value to their education, and by the pressure of poverty. There are various discrimination patterns such as harmful gender standards and lower social status of women and girls that really devalue the girls' education. Although primary school enrollment is increasing steadily, the primary education completion rates of girls' usually fall behind as well as their transition rate to secondary school. Girls who got married often argued to discontinue their education and stay at home [4]. Thus, Afghanistan's provision of education still discriminates against women by failing to take adequate measure to remedy the disparity in education participation between girls and boys.

\section{PROBLEM STATEMENT}

Today more girls than ever go to school. However, despite progress, Afghan women and girls continue to face a multiple barrier based on the gender and its intersection with various factors. According to a 2011 survey by Thomson Reuters Foundation, which identified Afghanistan as the most dangerous place in terms of conflict-related violence and domestic abuse, the worst access to healthcare, and a lack of access to economic resources. 
In all, UNICEF estimates that 3.7 million children are out of school in Afghanistan - 60\% of them are girls. That's 2.2 million girls left behind because of war and lack of adequate teaching facilities and women teachers. UNIFEM says that $87 \%$ of women face abuse and violence in Afghanistan. Human Rights Watch (HRW) reported that, in areas under Taliban control, women are facing constant threats, intimidation and violence. Girls' schools - and girls themselves - have been targeted along with female political leaders and activists, several of whom have reportedly been murdered.

According to Central Asia Institute, the fact that gender inequality in Afghan schools still has a number of influences. Women are expected to marry early, have children, stay at home. Security issues often create problems in travelling to/from schools. In a capital city of Kabul. Literacy rate are the highest in the nation for both genders.; $68 \%$ for men, $34.7 \%$ for women. In more remove provides gender and geographical de divides emerge; in Helmand province, the male literacy rate is rate is $41 \%$ percent [6]. According to a survey of Afghan people that was conducted by the same institute in 2019 , found that lack of educational opportunities is the biggest problem facing women (43.2\%), followed by lack of rights (34.1\%), lack of employment opportunities $(24.1 \%)$, violence $(18.1 \%)$, lack of services $(13.7 \%)$, and economic concerns $(9.6 \%)$.

The Afghan government's 2015 report showed that more than 8 million were children registered in schools, of which 39 percent were girls. The Ministry of Education in December 2016 stated that 6 million were children enrolled in schools. These figures originate from a government census of schoolchildren who join the school and then leave for three years until they return to school [7]. Based on statistics, even in the most optimistic means, the number of girls and women in Afghanistan who go to schools has never been higher than fifty percent. As reported by UNICEF's estimates in January 2016, forty percent of schoolchildren in Afghanistan did not attend school. The UNICEF adds that from 2010-2011, 66 percent of Afghan girls at secondary school age, younger than 12 to 15 , did not go to schools in contrast with 40 percent of boys of this age. The Afghan Ministry of Education knows that there are not many children in schools, but what are the key factors behind the deprivation of children, particularly girls from schooling, is a daunting and challenging question for the Ministry of Education[7].

Women are kept at home to do the housework. They are depended on their husbands and parents financially. [the afghani paper ] stated that major obstacles women face are poverty, insecurity, early marriage, norms marriage, harassments, family encouragement and lack of support, lack of female teachers, long distance from /to home to school, poor quality education, No girls' only school[8]. Education is one of the most critical areas of empowerment for women and girls. Therefore, it is critical for the Afghan government to focus on providing fair access to education for girls and women to create a sustainable economy, harmonious society, and sustainable development.

\section{OBJECTIVES}

The fundamental object of this paper is to create solutions utilizing the conceptual design technique through a validated business model that help women and girls in improving their knowledge, abilities, entrepreneurial skills, and values towards developing a harmonious and sustainable economy. This solution is expected to decrease women unemployment and gender inequality in Afghanistan. Moreover, to investigate the role of Malaysian University of the Future to overcome the problem of women and girls in education and provide them with equal access to education, health care, decent work, and representation in political and economic decision-making and gender parity all aspect of society. Moreover, to propose a business model options for the Malaysian University of the Future (UotF) that is relevant to the communities and contributes to the well-being of the society. Such a business model can be adapted by other universities in a way meeting their current and future international community engagement needs and provide them meaningful and useful values.

\section{METHODOLOGY}

This paper adopted the design and system thinking method to create a practical solution for the fair access to education for women and girls in Afghanistan. This solution includes carrying out a literature review and interview to identify key issues of the Afghan women and girls' education and gender inequality; formulating, devising, and validating a business model, and value proposition that helps to solve these issues. The focus in this paper will be mostly on understanding and formulating various possible solutions which enhanced the wellbeing of Afghan women and girls.

\section{LITERATURE REVIEW}

\section{A. Institutes of Higher Learning}

According to [12], the higher institutions of learning sought innovative solutions that will provide students with experiences that better equips them for the workforce. The trend goes beyond innovations that are related to institutional operations, generating a chance for institutions of higher learning seeking to establish a culture of innovation for their learners. These entrepreneurial campus partnerships accord students the opportunity to learn skills beyond conventional disciplinary knowledge and focus on workforce preparedness, giving graduates an edge when they enter the labor market. Faculties have the chance to absorb dynamic experiences into their coursework, and students who enter the workforce with the exposure gotten from the entrepreneurial mind-set are more ready for rapidly progressing business sectors. 


\section{B. The education of women in Afghanistan}

Gender inequality as a very prominent phenomenon exists in the economic, cultural, social, and political structures of Afghanistan. UNESCO says that "Afghanistan is one of the poorest and least educated countries in the world with large gender and geographical disparities in relation to access to education" (UNESCO Country Programming Document-UCPD, 2011). There are related investigations carried out concerning gender inequality in education by different research groups. The literature essentially points to religious and common beliefs, poverty, insecurity, ethnic customs, geographical obstacles, and lack of quality service or corruption in the government as major obstacles for female education in Afghanistan.

The government of Afghanistan builds fewer schools for girls in primary and secondary levels in contrast to boys. In bellow half of provinces in Afghanistan, women teachers are under 20 percent, which itself is a huge difficulty for female students. Various religious and traditional families in Afghanistan do not permit their girls to be taught by opposite gender instructors, especially as daughters become older. In addition to the influence of female teacher shortage on the education of girls, 41 percent of schools in Afghanistan do not have buildings that challenge girl's education in Afghanistan. Those schools that have a building but do not have toilets and clean water and that this matter concerns girl's education inappropriately too [7].

In Afghanistan, insecurity, hunger, and shortage of girl's schools, and decreasing global aids for girl's education are just one side of the challenges coin. The other side of the challenges coin is the predominant rigid cultural standards that prevent girls from attending schools. These unyielding social norms involve child marriage, not letting girls to co-education schools, not permitting the daughters being taught by male teachers, stopping girls from going to schools who have been victimized sexually, gender stereotype and family discrimination in daughters and sons, and the controlled patriarchal codes [4][9][10].

Traditionally, in Afghanistan, many Afghan families favor giving the son child better chances while disfavoring the daughter child despite the fact that providing equal social, financial, and political opportunities, education, property ownership, and leadership would benefit both genders. Yet, amongst diverse communities in Afghanistan, it is considered culturally that the available opportunities are supposed to be used by the boy child firstly, and then the girl child gets in for the second option [9]. Girls and women are seen as the receptacles of honour. Therefore, they stay in the family circle, observe the veil, and are voiceless. The honour of the family, the tribe, and ultimately the nation is spent in women.

\section{Sustainable Development Goals 5, 4 (SDGs)}

The 2030 Sustainable Development Agenda, adopted in 2015 by all member states of the United Nations, offers a global vision for stability and prosperity for people and the world, now and into the future. Ensuing equal access to higher education for students all background at the nation level is priorities for applying and adhering to a wider approach to globalization, including technology and intellectual training [11]. Higher education ensures that all youth and a substantial proportion of adults, both men and women, achieve literacy and numeracy. The SGD4 purpose is to ensure inclusive and equitable quality education and promote lifelong learning opportunities for all. It offers an opportunity for the global higher education community to evaluate how universities contribute, to step up and demonstrate that building a sustainable future depends on both knowledge creation and collaboration. SDG5 seeks to end violence and discrimination against women and girls, but also providing women and girls with equal access to education, health care, decent work, and representation in political and economic decision-making and gender parity all aspect of society. These processes will fuel sustainable economies and benefits societies and humanity in large.

\section{Humanizing Education}

A humanizing education relies on the pedagogy of educators to influence, navigate, and coexist within the sociopolitical context and practices of teacher leaders, students, administration, and community members. Educator 's pedagogy has a great impact on humanizing education in a society. Our educational program needs to have expert staffs that are well educated and should be able to address our women problems with proper solutions. Every society needs to humanize education in order to change socially and sustainable development. In order to humanize education among women, this program should enable them to address their educational and financial problems for taking equal part in the society.

In the current digital world, technology has affected education in many aspects accelerated the learning process. In many countries, the success rate of education is highly related to use of technology. Technology and education integration aim to develop into women with the knowledge, skill, values, and be able to bring prosperity for themselves and the society.

\section{E. University of the Future (UotF)}

Nowadays, as people are living in the age of technology revolution, higher education institutes need to make enormous changes, particularly with regard to educational business model development. In the future, the traditional education process is no longer appropriate since people use a technology-based device in their daily lives [14]. Hence, the University of the Future (UotF) has a big engagement with the technology. Several drivers of transformation such as globalization drives the higher education industry. To remain competitive and balanced, various studies have concluded that academies need a new business model. However, competition in the higher education sector is increasing, making it possible for universities to distinguish themselves by designing new and innovative models that deliver relevant and applicable knowledge in universal. 
According to [15], Institute of higher education will need to keep altering due to the change in the focus of interest, market, and business demand. There is no doubt that many of the higher learning institutions have implemented today's changes such as using new technologies but technology working as a support to the education system alone is not enough. Thus, It remains to be seen how higher education systems will leverage on pedagogical innovation, educational technologies, and accreditation, to help shape future citizens and create knowledge hand-in-hand with other actors and institutions in our societies.

\section{BUSINESS MODEL}

\section{* Business Model Canvas (BMC)}

Business Model Canvas (BMC) is a strategic management tool to easily define and communicate a business idea or concept in a coherent way. It explains a company's customers to be served, the values to be delivered and the related details of financing cost structure and how a business intends to make money. The nine building blocks of business model are listed and explained in this article.

\section{Customer segment}

This section identifies the various stakeholders that includes in this project. These customers need to liaise with each other for the welfare of Afghan community. This will help in educating Afghan women and girls of two different ages, (1) students from age 18 to 30, and (2) adults from age 31 to 45 . Identifying the right customers is critical to the success of the programe.

\section{Value Proposition}

This is the main focal point of this project since the goal of this BMC is to create values for the customers. The aim is to develop and enhance Afghan women and girl's information and knowledge for a harmonious and balanced educated society of Afghanistan. To create a society where women and girls can equally take part in developing the Afghan economic, education, politics, and other vital changes. Due to the weak economy and the free culture of education in Afghanistan, the first value this business model offers for Afghan women is free education. This free education will improve literacy programs regarding technology and other life skills like entrepreneurship, farming, cooking, tailoring, family care neighbors' rights and so forth. Other value propositions include entrepreneurship, remote job opportunities, and facilitating the Ummah. Additionally, this will also help them settle their financial concerns. The value proposition will be further clarified in the Values Proposition Canvas (VPC) table [2].

\section{$>$ Key Partner}

This program will be led by Malaysian-University as it 's comprehensiveness, the program will need numerous partners in delivering the promised Value Propositions to the diverse Customer Segments. The government of Afghanistan is one of the main partners that will assist in conquering the issues and providing facilities for Malaysian-University to help in providing balanced and entrepreneurship education for women and girls in Afghanistan. Likewise, the Afghan Ministry of Women Affairs and Ministry of Education to be the key partnership of educating and building the skills of Afghan women affairs. They are supposed to play a vital role in facilitating the education system for women and girls by providing educational centers, cooperating in the curriculum and so on. Private sectors, NGOs, UN, OIC, ISESCO and other universities are also expected to take part in assisting education and building the talents of the Afghan women and girls.

\section{$>$ Key Activities}

This involves the necessary activities to deliver the proposed value propositions for the customers. Amongst the key activities are providing fair access to balanced education educational program that includes online and physical classes that will be teaching core subjects such as Islamic studies, entrepreneurship, life skills. Besides that, there will be also facilities management, conference events, responsible innovation, sand research as part of the key activities for fair access to balanced education and entrepreneurship education as well as mentoring and coaching. Enhancing digital platform capabilities will be also considered as a key activity.

\section{$>$ Key resources}

The key resource includes competent staff, a digital platform that will help in delivering fair access to balanced education through online. Moreover, the Afghan Alumni of Malaysian-University and students are also important key resources that would help to educate the women in Afghanistan. Students and adults are to be trained and nurtured in e- marketing on-line capabilities for various business areas on products and services such as food, sewing, tailoring, etc.

\section{Customer relationship}

The relationship is another integral block of the BMC. Fortunately, with the advancement of technology, there will be connection with involve parties from anywhere and at any time. Based on the proposed BMC, there are various ways to get the staff, partners and customers connected. Some of these are face to face and online community buildings. For digital communication, there is a different affordable platform available in the market such as eLearning and e- marketplace. 


\section{Channels}

The channels are used for awareness and communication with the customer segments. In order to deliver the proposed values to the customers, there will be various physical as well as digital platforms utilized. In terms of physical channels, delivering the values through physical infrastructure such as Masjids. For the digital channel, they will be digital platforms such as websites, Televisions, mobile application, publications, eLearning and e-marketplace. The function of eLearning is to help Afghan women get education remotely from various lecturer. There will be eMarketing skills taught through both eLearning and physical classes.

\section{Cost structure}

Based on the key activities, key partnership, and key resources identification. The cost will need to be incurred for the digital platforms and its tools such as laptops, Internet, websites, mobile applications, and electricity as well books, stationery, government tax and staff salary. these costs will be collected from the Afghan Government, donors, Malaysian-University, and program revenue streams.

\section{Revenue stream}

This is the amount of many collected to MalaysianUniversity via various activities. The revenue stream will be from the grant of government of Afghanistan, Islamic development bank, Asian development bank and donation and endowments. The aim of this segment is to cover cost for providing education to women in Afghanistan.

\section{THE VALIDATED BMC AND VPC}

The initial business model of the Malaysian-University - In the form of BMC and VPC, was developed based on literature reviews and design thinking. An interviewed has been conducted an interview with the Head of Academic \& Social entrepreneurship and an Afghan professor at a local Malaysian university to validate the BMC. In addition, the value proposition canvas is validated by interviewing 10 women refugees and Afghan postgraduate students in Malaysia.

\begin{tabular}{|c|c|c|c|c|}
\hline $\begin{array}{c}\text { - } \quad \text { Government } \\
\text { - United Nations } \\
\text { - NGOs } \\
\text { - UNESCO } \\
\text { - Ministries of higher } \\
\text { education and women } \\
\text { affairs } \\
\text { - Researchers } \\
\text { - Local/International } \\
\text { universities } \\
\text { - Alumni }\end{array}$ & \begin{tabular}{|c|} 
Value Activities \\
Entrepreneurship \\
education programs \\
- Research \\
- Managing facilities \\
- $\quad$ Organizing \\
events \& discussions \\
Responsible research \& \\
innovation \\
Develop and enhance \\
digital platform \\
\end{tabular} & \begin{tabular}{|c|c|} 
Value Proposition \\
- & Reduce gender \\
inequality in Afghan \\
education \\
Free education \\
- \\
- $\begin{array}{c}\text { Provide remote job } \\
\text { opportunities }\end{array}$ \\
- Increase women \\
teachers \\
- Enhancing Afghan \\
Society well-being \\
- Produce women \\
entrepreneurs \\
- Enhance employment \\
opportunity for women \\
and girls \\
- Provide fair access to \\
balanced education \\
- Create decent work \\
- Improve economy
\end{tabular} & \begin{tabular}{|c|} 
Channels \\
- Physical \\
infrastructure \\
- Masjid \\
- Digital platforms: \\
eLearning \& \\
Marketplace \\
- publication
\end{tabular} & \begin{tabular}{|c|} 
Customer Segments \\
- Women \\
- $\quad$ Students (age \\
18 -30 ) \\
- Adults ( age 31-45) \\
- Donors \\
- Sponsors \\
- Volunteers \\
- Government of \\
Afghanistan \\
\end{tabular} \\
\hline $\begin{array}{r}- \\
- \\
- \\
- \text { Digital } \\
- \\
- \text { Staff } \\
\text {-Cost of facil }\end{array}$ & $\begin{array}{l}\text { Cost Structure } \\
\text { Cost of building } \\
\text { ost of stationaries } \\
\text { Cost of electricity } \\
\text { platform maintenance } \\
\text { Jovernmental tax } \\
\text { and lecturer's salary } \\
\text { ities management \& events }\end{array}$ & - Gran & $\begin{array}{r}\text { - Freemium fr } \\
\text { nment, ISESCO, IDB, } \\
\text { UNESCO gran } \\
\text { CSR: corporate social } \\
\text { - Donation and End } \\
-\quad \text { Consultancy } \\
\text { - Donation }\end{array}$ & $\begin{array}{l}\text { ees } \\
\text { ADB, UN funding, } \\
\text { tts } \\
\text { responsibility grant } \\
\text { owments } \\
\text { fees }\end{array}$ \\
\hline
\end{tabular}

Table 1:- Validated Business Model Canvas (BMC) 


\section{Value Proposition Canvas}

Value Proposition Canvas (VPC) is a tool for ensuring that a service or product is positioned within the customer needs and values. The value proposition defines the value of the program, services and products that are offered by the Malaysian UotF in satisfying the expectation and needs of the customer segments. After conducting interviews, the VPC shown in table 2 has been validated.

\begin{tabular}{|c|c|c|c|c|c|c|}
\hline $\begin{array}{l}\text { Customer } \\
\text { Segment }\end{array}$ & $\begin{array}{c}\text { Product } \\
\text { services }\end{array}$ & $\begin{array}{l}\text { Gain } \\
\text { creators }\end{array}$ & Pain relievers & $\begin{array}{l}\text { Customer } \\
\text { Job }\end{array}$ & Gains & Pains \\
\hline $\begin{array}{c}\text { Afghan } \\
\text { women and } \\
\text { girls } \\
\text { (students, } \\
\text { adults) }\end{array}$ & $\begin{array}{l}\text { Entrepreneurship } \\
\text { training } \\
\text { - Free education } \\
\text { - Quality education }\end{array}$ & $\begin{array}{l}\text { - Educational } \\
\text { program and } \\
\text { awareness. } \\
\text { - Events } \\
\text { - Educational } \\
\text { centers }\end{array}$ & $\begin{array}{c}\text {-Competent } \\
\text { staffs } \\
\text {-Technology } \\
\text {-Investment } \\
\text {-Research } \\
\text { - Beginner level } \\
\text { course }\end{array}$ & \begin{tabular}{|c|}
-Learn new \\
knowledge \\
and skills \\
- Attend the \\
education \\
center \\
- Use the \\
digital \\
platform
\end{tabular} & \begin{tabular}{|c|} 
- Obtain \\
new \\
knowledge \\
\& skills \\
- Better \\
financial \\
outlook \\
- Educated \\
community \\
- Distance \\
Leaning \\
\end{tabular} & \begin{tabular}{|c|}
-lack of \\
knowledge \\
- poverty \\
- $\quad$ Lack of access to \\
education \\
- Unemployment \\
- $\quad$ Being wrong \\
gender
\end{tabular} \\
\hline Donors & $\begin{array}{l}\text { - Reduce unemployment } \\
\text { - Skilled entrepreneurs } \\
\text { - eLearning platform }\end{array}$ & $\begin{array}{l}\text { - Humanizing } \\
\text { education } \\
\text { - Helping the } \\
\text { ummah. } \\
\text { - Free rendered } \\
\text { services }\end{array}$ & \begin{tabular}{|c|} 
Quality digital \\
platform \\
integrated with \\
E-payment and \\
E- commerce \\
- Professional \\
instructors \& \\
- Quality \\
content \\
\end{tabular} & \begin{tabular}{|}
-Giving \\
charity and \\
zakat \\
-Making a \\
contribution \\
to society 's \\
wellbeing
\end{tabular} & \begin{tabular}{|c|}
-Developed \\
harmonized \\
society \\
-Creating \\
balanced \\
talents and \\
decent work
\end{tabular} & $\begin{array}{l}- \\
\text { Spend money } \\
\text { and time } \\
-\quad \text { Spend } \\
\text { resources }\end{array}$ \\
\hline Volunteers & $\begin{array}{l}\text { - Research \& innovation skills } \\
\text {-Global } \\
\text { Networking } \\
\text { - } \quad \text { Open online courses }\end{array}$ & $\begin{array}{l}\text { Research } \\
\text { rants } \\
\text { - Professional } \\
\text { volunteers }\end{array}$ & \begin{tabular}{|c|}
-Help remotely \\
-Devote free or \\
part-time \\
- Help on \\
vocation time
\end{tabular} & \begin{tabular}{|c|} 
Train \\
women and \\
girls \\
- job \\
opportunities \\
- research
\end{tabular} & \begin{tabular}{|c|}
-Serve the \\
community. \\
-Society \\
well- being \\
-Bright \\
future \\
-Branch in \\
self- \\
knowledge
\end{tabular} & $\begin{array}{c}\text { - Free teaching - Spend } \\
\text { time and energy and } \\
\text { money }\end{array}$ \\
\hline $\begin{array}{l}\text { Government } \\
\text { of } \\
\text { Afghanistan }\end{array}$ & $\begin{array}{c}\text { Trusted \&competent in } \\
\text { delivering humansing } \\
\text { educational programme }\end{array}$ & $\begin{array}{c}- \\
\text { Universities and } \\
\text { schools } \\
\text { MOWA, } \\
\text { MOHE }\end{array}$ & \begin{tabular}{|c|} 
- Universities \& \\
buildings \\
during holidays \\
- Effective \\
Communication \\
channel \\
Masjids as \\
physical \\
infrastructure
\end{tabular} & \begin{tabular}{|c|} 
- Help IIUM \\
in reaching \\
out the \\
women \\
-Help in \\
making \\
curriculum \\
for women \\
and girls \\
-Enhance \\
educational \\
policies
\end{tabular} & \begin{tabular}{|c|}
- An \\
educated \\
and \\
balanced \\
society \\
-Developed \\
economy \\
-balanced \\
talents
\end{tabular} & $\begin{array}{c}\text { Misperception } \\
\text { regarding women } \\
\text { education } \\
\text { - Illiteracy } \\
\text { - Treating women as } \\
\text { second citizens } \\
\text {-Poverty } \\
\text {-Lack of teaching } \\
\text { materials }\end{array}$ \\
\hline
\end{tabular}

Table 2:- Validated value proposition canvas (VPC)

\section{CONCLUSION AND FUTURE WORK}

Cultural barriers are one of the main obstacles to the growth and spread of girls' education in Afghanistan. A large part of these cultural norms is learned through the process of socialization that shapes our lives. In this context, one of the most important ways of development and transformation in each society is to challenge and ignore the norms that for various reasons are no longer responsive and meaningful for a group or stratum. According to the literature review, the biggest problem among women and girls in Afghanistan is lack of literacy. Poverty, early marriage, female feticide, and population burst originate form illiteracy. To develop a sustainable harmonious society, there must be a substantial increase in the number of women and girls who have relevant 
knowledge, skills, and human values for entrepreneurship, employments, and decent jobs to take equal part in education, economy and so on.

This paper proposes a business model for MalaysianUniversity of the Future to involve in community engagement activities which can leverage in helping to reduce gender inequality in education that Afghan women and girls are facing. The contribution of this paper includes offering a conceptual and validated business model in BMC and VPC format. This conceptual business model can be further personalized by other academies for sustainable societal engagement events [initiatives]. For the future work, this conceptual business model will be translated into real implementation by preparing a business plan, with a project and change management plan for this programme.

\section{REFERENCES}

[1]. Abukari, Abdulai. 2014. "Education of Women in Islam: A Critical Islamic Interpretation of the Quran." Religious Education 109(1): 4-23. https://doi.org/10.1080/00344087.2014.868203.

[2]. Wilson, C. (2018 July 3). TOP 10 FACTS ABOUT GIRLS“ EDUCATION IN AFGHANISTAN. Retrieved from https://borgenproject.org/facts-aboutgirls-education-in-afghanistan.

[3]. Ibrahim, J., \& Dahlan, A. R. A. (2016). Designing business models options for -University of the Future.\| Colloquium in Information Science and Technology, CIST, O(August 2017), 600-603. https://doi.org/10.1109/CIST.2016.7804956

[4]. Mashwani, H. U. (2017). Female Education in Afghanistan: Opportunities and Challenges Female Education in Afghanistan: Opportunities and Challenges, 3(11), 43-49.

[5]. Reilly, Amanda, Deborah Jones, and Jayne Krisjanous. 2016. "Confronting Gender Inequality in a Business School." Higher Education Research and Development 35.

[6]. Gender Equality in Afghan Education: Building a new start for a nation in turmoil - The Asia Foundation. (n.d.). December 20th, 2018. Available on https://centralasiainstitute.org/gender-equality-inafghan-education-building-a-new-start-for-a-nationin-turmoil/

[7]. Barr, H. (2017). I won't be a doctor and one day you'll be sick: girls' access to education in Afghanistan (pp. 5-20). New York, NY: Human Rights Watch

[8]. Bamik, Hamidullah. 2018. "Afghanistan's Cultural Norms and Girls' Education: Access and Challenges." 4: 83-93.

[9]. Burde, D., \& Linden, L. L. (2013). Bringing education to Afghan girls: A randomized controlled trial of villagebased schools. American Economic Journal: Applied Economics, 5(3), 27-40.

[10]. (2015). Gender inequality in education in Afghanistan: Access and barriers. Open Journal of Philosophy, 5(05), 277.
[11]. Winasis, F. and Dahlan, A. R. A. (2019). Reshaping University of the future: Designing Business Models that are relevant through humanising education and 4IR. Reshaping University of the future: Designing Business Models that are relevant through humanising education and 4IR. 7(1), 1-12.

[12]. B.-M. D. K. M. W. B. Alexander \& Ashford-Rowe, "EDUCAUSE Horizon Report: 2019 Higher Education Edition," EDUCAUSE, 2019.

[13]. How To Use The Value Proposition Canvas - 10 Step Guide Plus Free Templates. Retrieved on July 2020 from https://www.garyfox.co/canvas-models/valueproposition-canvas-guide/

[14]. Yahya, N. Z. and Dahlan, A. R. A. (2019). University of the future ( UotF ): Redesign Business Model for local University in Malaysia through humanising education and 4IR. 8(1), 64-70.

[15]. Faizan, Faizullah, Ghafari, Abdullah, Hussein, Mohamed, \& Dahlan, A. (2018). University of the Future: A Conceptual Business Model of University Putra Malaysia. International Journal of Computer Science and Information Technology Research, 6(2 (April-June)), 206-216. 